\title{
Effects of Two Salts Compounds on Mycelial Growth, Sporulation, and Spore Germination of Six Isolates of Botrytis cinerea in the Western North of Algeria
}

\author{
Boualem Boumaaza, ${ }^{1}$ Mohamed Benkhelifa, ${ }^{1}$ and Moulay Belkhoudja ${ }^{2}$ \\ ${ }^{1}$ Department of Agronomy, Laboratory of Plant Protection, University of Abdelhamid Ibn Badis, BP 300, 27000 Mostaganem, Algeria \\ ${ }^{2}$ Sciences Faculty, Vegetal Ecophysiology Laboratory, University of Es Senia, BP 1524, ElMnouer, Oran, Algeria
}

Correspondence should be addressed to Boualem Boumaaza; agroboum@hotmail.fr

Received 19 December 2014; Revised 26 February 2015; Accepted 5 March 2015

Academic Editor: Maurizio Sanguinetti

Copyright (C) 2015 Boualem Boumaaza et al. This is an open access article distributed under the Creative Commons Attribution License, which permits unrestricted use, distribution, and reproduction in any medium, provided the original work is properly cited.

\begin{abstract}
Six isolates of Botrytis cinerea were isolated from leaves and stems of different tomato varieties taken from four areas in the northwest of Algeria where tomato is mostly grown in greenhouses and high tunnels. The purpose of this research was to determine the effect of two salts, $\mathrm{NaCl}$ and $\mathrm{CaCl}_{2}$, on three stages of Botrytis cinerea's life cycle. All isolates tested were stimulated in 50 to $150 \mathrm{ppm} ; \mathrm{NaCl}$ was the most effective treatment to increase mycelial growth at two tested concentrations. However, at 300 ppm concentration, $\mathrm{CaCl}_{2}$ completely inhibited the growth of mycelium; they reach $34.78 \%$ for the isolate TR46 and $26.72 \%$ for isolate F 27 . The sodium and calcium salts stimulated conidia production in liquid culture. We noticed that the effect of calcium chloride on sporulation was average while sodium chloride. In the medium containing $50 \mathrm{ppm}$, calcium chloride and sodium chloride increased the germination capacity of most isolates compared with the control. Other calcium salts, at 100 or $300 \mathrm{ppm}$, decreased the germination percentage of the conidia. With the exception of sodium salts, the inhibitions of germination reduce at 150 or 300 compared with the control. Conidial germination was slightly inhibited by sodium chloride only when the concentration was over $300 \mathrm{ppm}$.
\end{abstract}

\section{Introduction}

Grey mould, caused by Botrytis cinerea (Sclerotiniaceae family), is an important plant disease that affects a large number of plant species and is particularly important in greenhouse production of tomatoes in the Mediterranean Basin [1]. In greenhouse tomato, the fungus infects flowers, fruits, and leaves and can grow through the petiole into the stem $[2,3]$.

Soil salinity is a major constraint to agricultural production around the world. This problem is one of the major stresses especially in arid and semiarid regions [4] and can severely limit plant growth and productivity $[5,6]$.

In Algeria, a wide range of environmental stresses (such as high and low temperature, drought, alkalinity, salinity, and pathogen infection) are potentially harmful to the plants. Soil salinity and irrigation water are two of the main serious problems hindering the development of most plant species [7].
Thus, the effect of these factors may result from structural and physiological changes in the plant, an increased incidence, and severity of diseases caused by various species pathogen. Reference [8] showed that relatively low levels of salinity (25-50 mEq) could increase the severity of Phytophthora root rot of tomato with high $\mathrm{Na}$ : Ca ratios (10:1), Phytophthora [9-12], F. oxysporum f. sp. vasinfectum [13], F. oxysporum f. sp. radicis-lycopersici [14], and Verticillium dahliae and Alternaria solani [15].

$\mathrm{Ca}$ is an essential element in all plants [16]. The ability of $\mathrm{Ca}$ to form intermolecular linkages gives it an important role in maintaining the integrity and structure of membranes and cell walls [17]. Ca is also used as a second messenger in many signal transduction pathways within the cell [18]. Its role in the physiology of plant tissue is well established [19]. Several studies have reported that Ca treatment of plant tissue induces an increase in tissue Ca content [20], resulting in reduced fungal diseases. The mechanisms by 
which calcium salts inhibit the development and severity of diseases are not known. One hypothesis is that high external $\mathrm{Ca}^{2+}$ concentrations may increase the concentration of $\mathrm{Ca}^{2+}$ in the cytosol, which can be toxic to the fungus. The ability of calcium to reduce the development of postharvest diseases of fruit has been attributed mainly to the formation of calcium cross-linkages in the cell wall, resulting in decreased effectiveness of cell wall-macerating enzymes secreted by the pathogen [21]. Reference [22] also demonstrated a relationship between increasing levels of calcium in the cell walls of potato tubers and a reduction in the macerating activity of Erwinia carotovora.

All the studies on the effect of Ca on Botrytis showed that it has an inhibitory effect on growth of this fungus at high concentrations [23-25]. This effect is thought to be mainly due to the role of calcium in ameliorating physiological disorders and thus indirectly reducing pathogen activity [26, 27]. Reference [25] has indicated that calcium chloride reduced germination and germ tube elongation of B. cinerea and Penicillium expansum in vitro. Reference [28] also has reported a similar effect of calcium in reducing the susceptibility of rose flowers to gray mold caused by Botrytis cinerea.

For the most effective control of disease, it seems necessary to examine the impact of salinity on the development of pathogen. The objective of this study was to determine the in vitro effect of sodium and calcium salts on spore production, conidia germination, and mycelial growth of B. cinerea.

\section{Materials and Methods}

2.1. Fungal Isolates. B. cinerea isolates were obtained from decayed tomato (Lycopersicon esculentum) in northwestern Algeria. The leaf fragments were placed on filter paper moistened with sterile water in a Petri dish. B. cinerea was cultured on potato dextrose agar (PDA) incubated at $25^{\circ} \mathrm{C}$. Conidia were harvested from 14-day-old cultures by agitating small pieces of agar, bearing mycelia and conidia, in a glass tube.

2.2. Effect on Sporulation. Conidia of B. cinerea were obtained from 2 week old PDA cultures incubated at $25^{\circ} \mathrm{C}$ in $12 / 12$ hours light/dark. Culture plates were vortexed in a tube containing $10 \mathrm{~mL}$ sterile distilled water and $0.05 \mathrm{~mL}$ Tween 80. A sterile magnetic stir bar was placed on the agar and set stirring for 5 minutes to loosen the spores. The suspension enriched in spores was filtered through glass filter to eliminate mycelium. Finally the conidial concentration was determined using a Malassez cell and adjusted to $10^{5}$ spores per $\mathrm{mL}$.

2.3. Effect on the Germination of Conidia. To determine the influence of $\mathrm{NaCl}$ and $\mathrm{CaCl}_{2}$ on spore germination of $B$. cinerea, a drop containing 100 conidia was transferred onto water agar plates enriched with $\mathrm{NaCl}$ and $\mathrm{CaCl}_{2}: 0,50,100$, 150 , and $300 \mathrm{mEq}$. The plates were incubated at $25^{\circ} \mathrm{C}$ in the dark for 24 hours. Results were expressed as the percentage of germinated conidia. A conidium was considered as germinated if the germ tube length was at least twice the length of the conidium.

2.4. Effect on Mycelial Growth. The influence of $\mathrm{NaCl}$ and $\mathrm{CaCl}_{2}$ on the diameter growth was determined by growing the isolates in a PDA medium at four $\mathrm{NaCl}$ and $\mathrm{CaCl}_{2}$ levels $(50,100,150$, and $300 \mathrm{mEq})$; control medium was not amended with salts. Mycelium growth inhibition was evaluated by placing a plug ( $4 \mathrm{~mm}$ diameter) from an actively growing culture in the centre of a PDA agar plate of $9 \mathrm{~cm}$ plastic Petri dishes. Cultures were incubated for $7-14$ days at $25^{\circ} \mathrm{C}$ in the dark, and each treatment had four replications. Colony diameters were measured at two perpendicular directions.

2.5. Statistical Analysis. All statistical analyses were analyzed by the software of statistics (STATBOX 6.0.4, Grimmersoft). The data were analyzed by two-way factorial. Comparison of means and interactions was performed by Duncan's multiple range tests. Statistical significance was assessed at the level of $P=0.05$ or $P=0.01$.

\section{Results}

Morphological Characteristics. All the isolates exhibited variation in their colony characteristics such as color, shape, and texture (Figure 1).

B. cinerea colonies from tomato on PDA at $25^{\circ} \mathrm{C}$ were visually classified into three morphological groups, GI, GII, and GIII, based on colony color and pycnidial distribution. GI (F27) isolate produced white to light grey colonies, where colony texture was generally cottony, and was present at the center of the Petri dish. GII (FA13, S27, B27, and TR13) isolates had off-white to pale gray color. Colonies generally had a medium texture. GIII (R13) isolate had grown and spread rapidly by aerial mycelia growth. The colony was generally grey color. Based on the morphological parameter of length, pycnidia can be classified into two groups: length greater in isolates FA13, S27, B27, and F27 and length less in isolates TR13 and R13. Sclerotia also vary in abundance and distribution. In some isolates both superficial and imbedded sclerotia were produced. They scattered all over the medium in Petri dish, covering the entire surface of the agar (B27 and TR13 and F27). In some isolates sclerotia were produced on concentric rings, formed along the edges of the Petri dish (FA13, S27, and R13). Sclerotia were variable in shape and size. They were black, rounded, roughly circular, or irregular in shape.

3.1. The Effects of $\mathrm{NaCl}$ and $\mathrm{CaCl}_{2}$ of Culture Medium on Mycelial Growth of Six Isolates. This study evaluated the activity of 2 salts against $B$. cinerea in vitro at 4 concentrations. The effect of salts at different concentrations on mycelial growth of colonies of six isolates of $B$. cinerea in PDA was observed after 3 days. The results are shown in Table 1 . All concentrations, except $300 \mathrm{ppm}$, of $\mathrm{NaCl}$ significantly stimulated growth of B. cinerea. $(P<0.001)$. Beyond this range, reduced growth has been correlated with the increasing in the $\mathrm{NaCl}$ of the medium.

The calcium chloride at 50 and $100 \mathrm{ppm}$ stimulated mycelial growth of $B$. cinerea relative to the control. However, 



(a)

(b)

FIGURE 1: Morphological types of B. cinerea. (b) Mycelial growth on potato dextrose agar (PDA) medium at $25^{\circ} \mathrm{C}$ after two weeks. (a) Distribution and pattern of sclerotia formation on the surface of PDA after 4 weeks.

higher concentrations of calcium chloride (150 and $300 \mathrm{ppm}$ ) caused F27, B27, R13, TR46, S27, and FA13 to reduce growth by $26.72,24.26,23.24,34.78,15.07$, and $17.04 \%$, respectively. There was a significant reduction in growth of isolates $(P<$ 0.001 ) with increasing calcium salt. At $300 \mathrm{ppm}$, calcium chloride was the most inhibitory, reducing growth on PDA by $34.78 \%$ for the isolate. The interaction between salt and concentration was significant for R13, TR45, S27, and FA13 $(P<0.001)$, but not significant for F27 and B27 isolates.

All concentrations were significantly different from the control $(P<0.001) ; 150 \mathrm{ppm} \mathrm{CaCl}_{2}$ and $300 \mathrm{ppm} \mathrm{NaCl}$ or $\mathrm{CaCl}_{2}$ were similar to each other and different from other concentrations in reducing mycelial growth.

3.2. The Effects of $\mathrm{NaCl}$ and $\mathrm{CaCl}_{2}$ on the Production of Spores of the Six Isolates. In the absence of salt (Table 2), isolates of $B$. cinerea do not present the same profile of conidial production.

The optimum density for spore production of this fungus was from $1.9710^{6}$ to $2.210^{6}$ spores $/ \mathrm{mL}$, of $\mathrm{R} 13$ and $\mathrm{B} 27$, respectively. Data in Table 2 indicate that application of chloride salts and sodium salt caused a significant increase in the production of conidiogenesis at various concentrations tested compared with control $(P<0.001)$. However, these observations indicate that the conidial production of the six isolates might increase, even at high salinity. There was a significant increase in these characters between the control and $50 \mathrm{ppm}$ concentration of salinity.

Under these salt conditions, sodium chloride is most favorable to the sporulation of all isolates of $B$. cinerea, especially at high concentrations of the culture medium. By adding $300 \mathrm{ppm}$ of $\mathrm{NaCl}$ to the culture medium, an increase in spore production by $1.2110^{7}$ spores $/ \mathrm{mL}$ can be obtained from the isolate B27. Calcium chloride stimulates little sporulation of the isolates, with only $9.210^{6} / \mathrm{mL}$ to isolate R13. The amount of spore production is in direct proportion to the concentration of salinity in the culture medium. The interaction between salt and concentration was significant for all salts isolates $(P<0.05)$ except FA13 (Table 2$)$.

The results for the percentage germination of different isolates studied in terms of germination capacity under the effect of different salt concentrations are shown in Table 3.

The six isolates presented dissimilar percentages of germination in the presence of sodium and calcium chloride. The analysis shows that salinity affects the percentage of germination for each value of salt. There are significant 
TABLE 1: Effect of different concentrations of $\mathrm{NaCl}$ and $\mathrm{CaCl}_{2}$ on the percentage of mycelial growth areas (millimeter) of six isolates of Botrytis cinerea in PDA medium after incubation at $25^{\circ} \mathrm{C}$ for 3 days.

\begin{tabular}{|c|c|c|c|c|c|c|}
\hline \multirow{2}{*}{ Treatment } & \multicolumn{6}{|c|}{ B. cinerea isolate } \\
\hline & F27 & B27 & $\mathrm{R} 13$ & TR46 & S27 & FA13 \\
\hline Control & $36.16^{\mathrm{a}}$ & $38.5^{\mathrm{c}}$ & $40.16^{\mathrm{c}}$ & $38.33^{\mathrm{b}}$ & $31^{\mathrm{cd}}$ & $37.16^{\mathrm{cd}}$ \\
\hline \multicolumn{7}{|l|}{$\mathrm{NaCl}$} \\
\hline 50 & $37.83^{\mathrm{ab}}$ & $42^{\mathrm{b}}$ & $41.5^{\mathrm{bc}}$ & $41.2^{\mathrm{a}}$ & $35.16^{\mathrm{ab}}$ & $38.66^{\mathrm{abc}}$ \\
\hline 100 & $38.5^{\mathrm{a}}$ & $44.33^{\mathrm{a}}$ & $45.5^{\mathrm{a}}$ & $43.5^{\mathrm{a}}$ & $37.83^{\mathrm{a}}$ & $40.33^{\mathrm{a}}$ \\
\hline 150 & $38^{\mathrm{a}}$ & $41.5^{\mathrm{c}}$ & $44^{\mathrm{ab}}$ & $43^{\mathrm{a}}$ & $37.66^{\mathrm{a}}$ & $39.83^{\mathrm{ab}}$ \\
\hline 300 & $31.16^{\mathrm{d}}$ & $31.33^{\mathrm{d}}$ & $32.16^{\mathrm{de}}$ & $32.66^{\mathrm{d}}$ & $28.33^{\mathrm{de}}$ & $28^{\mathrm{f}}$ \\
\hline \multicolumn{7}{|l|}{$\mathrm{CaCl}_{2}$} \\
\hline 50 & $36.5^{\mathrm{a}}$ & $40.5^{\mathrm{b}}$ & $41.33^{\mathrm{bc}}$ & $40.83^{\mathrm{ab}}$ & $32.66^{\mathrm{bc}}$ & $38.33^{b c}$ \\
\hline 100 & $37^{\mathrm{d}}$ & $42^{\mathrm{a}}$ & $42.5^{\mathrm{bc}}$ & $42.5^{\mathrm{a}}$ & $34.16^{\mathrm{bc}}$ & $39.5^{\mathrm{ab}}$ \\
\hline 150 & $33.5^{\mathrm{a}}$ & $37.33^{\mathrm{a}}$ & $34^{\mathrm{d}}$ & $35.5^{\mathrm{c}}$ & $28.66^{\mathrm{de}}$ & $36^{\mathrm{d}}$ \\
\hline 300 & $26.5^{\mathrm{e}}$ & $29.16^{\mathrm{c}}$ & $30.83^{\mathrm{e}}$ & $25^{\mathrm{e}}$ & $26.33^{\mathrm{e}}$ & $30.83^{\mathrm{e}}$ \\
\hline \multicolumn{7}{|c|}{ Two-way factor analysis of variance } \\
\hline Salt & $P=001$ & $P=00018$ & $P=0.00001$ & $P=0$ & $P=0.00001$ & $P=0$ \\
\hline Concentration & $P=0$ & $P=0$ & $P=0$ & $P=0$ & $P=0$ & NS \\
\hline Salt $*$ concentration & NS & NS & $P=0.0001$ & $P=0.00001$ & $P=0.001$ & $P=00004$ \\
\hline
\end{tabular}

$P=$ probability value (significance level). NS; not significant. Z: Letters denote significant differences among means in columns within trial according.

TABLE 2: Effect of different concentrations of $\mathrm{NaCl}$ and $\mathrm{CaCl}_{2}$ on sporangium formation by six isolates of Botrytis cinerea in vitro after 14 days in potato dextrose agar $(\mathrm{PDA})$ at $25^{\circ} \mathrm{C}$.

\begin{tabular}{|c|c|c|c|c|c|c|}
\hline \multirow{2}{*}{ Treatment } & \multicolumn{6}{|c|}{ B. cinerea isolate } \\
\hline & F27 & B27 & $\mathrm{R} 13$ & TR46 & S27 & FA13 \\
\hline Control & $14.25^{\mathrm{c}}$ & $22.7^{\mathrm{c}}$ & $19.75^{\mathrm{d}}$ & $20.2^{\mathrm{b}}$ & $10.37^{\mathrm{d}}$ & $8.87^{\mathrm{d}}$ \\
\hline \multicolumn{7}{|l|}{$\mathrm{NaCl}$} \\
\hline 50 & $26.49^{c}$ & $29.55^{\mathrm{c}}$ & $21.16^{\mathrm{d}}$ & $22.57^{\mathrm{b}}$ & $20.39^{c}$ & $21.1^{\mathrm{c}}$ \\
\hline 100 & $31.33^{b c}$ & $31.33^{\mathrm{c}}$ & $45.54^{\mathrm{c}}$ & $35.62^{\mathrm{b}}$ & $32.04^{\mathrm{d}}$ & $29.58^{\mathrm{b}}$ \\
\hline 150 & $63.04^{\mathrm{b}}$ & $57.62^{\mathrm{b}}$ & $88.41^{\mathrm{b}}$ & $41.87^{\mathrm{b}}$ & $68.65^{\mathrm{b}}$ & $35.66^{\mathrm{b}}$ \\
\hline 300 & $109.25^{\mathrm{a}}$ & $121.45^{\mathrm{a}}$ & $107.49^{\mathrm{b}}$ & $95.83^{\mathrm{b}}$ & $95.53^{\mathrm{a}}$ & $56.11^{\mathrm{a}}$ \\
\hline \multicolumn{7}{|l|}{$\mathrm{CaCl}_{2}$} \\
\hline 50 & $27.29^{c}$ & $26.96^{\mathrm{c}}$ & $24.74^{\mathrm{d}}$ & $21.29^{\mathrm{b}}$ & $34.5^{\mathrm{c}}$ & $15.95^{\mathrm{d}}$ \\
\hline 100 & $27.62^{c}$ & $32.41^{\mathrm{c}}$ & $28.19^{\mathrm{cd}}$ & $24.33^{\mathrm{b}}$ & $31.54^{\mathrm{c}}$ & $28.16^{\mathrm{C}}$ \\
\hline 150 & $35.33^{b c}$ & $36.36^{\mathrm{c}}$ & $45.66^{\mathrm{c}}$ & $28.74^{\mathrm{b}}$ & $46.66^{\mathrm{c}}$ & $35.33^{\mathrm{b}}$ \\
\hline 300 & $59.16^{\mathrm{b}}$ & $67.47^{\mathrm{b}}$ & $90.29^{\mathrm{a}}$ & $54.37^{\mathrm{a}}$ & $73.7^{\mathrm{b}}$ & $59^{\mathrm{a}}$ \\
\hline \multicolumn{7}{|c|}{ Two-way factor analysis of variance } \\
\hline Salt & $P=0.0005^{\mathrm{z}}$ & $P=0.0008$ & $P=0.024$ & NS & $P=0.034$ & NS \\
\hline Concentration & $P=0$ & $P=0$ & $P=0$ & $P=0.00002$ & $P=0$ & $P=0$ \\
\hline Salt $*$ concentration & $P=0.008$ & $P=0.00009$ & $P=0.00001$ & $P=0.029$ & $P=000018$ & NS \\
\hline
\end{tabular}

$P=$ probability value (significance level). NS; not significant. Z: Letters denote significant differences among means in columns within trial according.

differences between saline treatments. The highest germination percentage, $78.33 \%$ and $63.67 \%$, was obtained in the absence of salt after $24 \mathrm{~h}$ incubation at $25^{\circ} \mathrm{C}$, from isolates FA13 and TR46, respectively. Concerning the salts, the 50 and $100 \mathrm{ppm}$ also increased the conidial germination except TR13 and FA13 isolates, which was significantly different from the stimulation caused by $\mathrm{NaCl}$. Conversely, spore germination was decreased for sodium concentrations of 150 and $300 \mathrm{ppm}$ relative to the control.

The application of lower concentrations of $\mathrm{CaCl}_{2}$ (50 ppm) to wounds did not inhibit their percentage germination. However, germination percentages were very low in all concentrations except $50 \mathrm{ppm}$. $\mathrm{CaCl}_{2}$ was toxic at lower concentrations than the other salts. The toxicity of calcium chloride $(\mathrm{EC} 50=100 \mathrm{ppm})$ to spores was higher than that of sodium chloride $(\mathrm{EC} 50=150 \mathrm{ppm})$. The interaction between salt and concentration was significant for all isolates $(P<0.001)$ except F27 and TR46.

\section{Discussion}

The purpose of this study was to compare the effect of sodium and calcium salts against $B$. cinerea. Our in vitro tests showed that sodium chloride stimulates the development of 
TABLE 3: The effect of sodium and chloride salts on the germination of Six Isolates of Botrytis cinerea (percent germination was measured ater $24 \mathrm{~h}$ incubation at $25^{\circ} \mathrm{C}$ ).

\begin{tabular}{|c|c|c|c|c|c|c|}
\hline \multirow{2}{*}{ Treatment } & \multicolumn{6}{|c|}{ B. cinerea isolate } \\
\hline & F27 & B27 & $\mathrm{R} 13$ & TR46 & S27 & FA13 \\
\hline Control & $54^{\mathrm{b}}$ & $56^{\mathrm{b}}$ & $58.66^{\mathrm{ab}}$ & $63.67^{\mathrm{a}}$ & $50.33^{\mathrm{d}}$ & $78.33^{\mathrm{b}}$ \\
\hline \multicolumn{7}{|l|}{$\mathrm{NaCl}$} \\
\hline 50 & $69^{\mathrm{a}}$ & $67.33^{\mathrm{a}}$ & $61.66^{\mathrm{ab}}$ & $64.66^{\mathrm{a}}$ & $66.66^{\mathrm{a}}$ & $90.66^{\mathrm{a}}$ \\
\hline 100 & $66.33^{\mathrm{a}}$ & $68.33^{\mathrm{a}}$ & $60.66^{\mathrm{ab}}$ & $32.33^{\mathrm{b}}$ & $61.33^{\mathrm{b}}$ & $63.33^{\mathrm{c}}$ \\
\hline 150 & $50.33^{\mathrm{b}}$ & $52^{\mathrm{b}}$ & $34.33^{\mathrm{c}}$ & $26.33^{\mathrm{b}}$ & $57.33^{c}$ & $61.66^{\mathrm{c}}$ \\
\hline 300 & $41^{\mathrm{c}}$ & $33.33^{\mathrm{c}}$ & $32.33^{\mathrm{c}}$ & $23^{\mathrm{b}}$ & $39.33^{\mathrm{e}}$ & $42.66^{\mathrm{e}}$ \\
\hline \multicolumn{7}{|l|}{$\mathrm{CaCl}_{2}$} \\
\hline 50 & $58^{\mathrm{a}}$ & $60.33^{\mathrm{ab}}$ & $69.66^{\mathrm{a}}$ & $65.33^{\mathrm{a}}$ & $55^{\mathrm{c}}$ & $88^{\mathrm{a}}$ \\
\hline 100 & $50^{\mathrm{ab}}$ & $51^{\mathrm{b}}$ & $55.33^{\mathrm{ab}}$ & $39.66^{\mathrm{b}}$ & $41.33^{\mathrm{e}}$ & $49.66^{\mathrm{d}}$ \\
\hline 150 & $45^{\mathrm{b}}$ & $29.33^{c}$ & $50.66^{\mathrm{b}}$ & $35.66^{\mathrm{b}}$ & $36.33^{\mathrm{f}}$ & $38.33^{\mathrm{e}}$ \\
\hline 300 & $33.33^{\mathrm{c}}$ & $25.66^{\mathrm{c}}$ & $18.29^{\mathrm{d}}$ & $30.33^{\mathrm{b}}$ & $18.33^{\mathrm{g}}$ & $28.33^{\mathrm{f}}$ \\
\hline \multicolumn{7}{|c|}{ Two-way factor analysis of variance } \\
\hline Salt & $P=0.00001^{\mathrm{z}}$ & $P=0$ & NS & $P=0.04$ & $P=0$ & $P=0$ \\
\hline Concentration & $P=0$ & $P=0$ & $P=0$ & $P=0$ & $P=0$ & $P=0$ \\
\hline Salt $*$ concentration & NS & $P=0.001$ & $P=0.0007$ & NS & $P=0$ & $P=0.0003$ \\
\hline
\end{tabular}

$P=$ probability value (significance level). NS; not significant. Z: Letters denote significant differences among means in columns within trial according.

the fungal up to $150 \mathrm{ppm}$. In contrast, only calcium salts were effective at low concentrations as compared to sodium chloride. However, higher concentrations of calcium chloride reduced mycelial growth of $B$. cinerea PDA medium.

Our data indicate that salinity stimulated growth of all six isolates at high concentration ( $\mathrm{NaCl}$ at up to $150 \mathrm{ppm})$. On the contrary, high salinity (more than $300 \mathrm{ppm}$ ) of several sodium has been shown to decrease mycelial growth and inhibit spore germination. Reference [29] showed that increasing the salinity of the medium promotes the in vitro mycelial growth of Phytophthora citrophthora and $P$. parasitica, agents of root rot of citrus, with an optimum between -1.44 and -3.11 bars. Similarly, [23] showed that all calcium salts tested (except formate, calcium pantothenate, and dibasic calcium phosphate) reduced the growth of Monilia fructicola responsible for brown rot of peach, on amended potato dextrose agar (PDA).

In the comparison of the inhibitory effect of the various salts, higher concentrations with $300 \mathrm{ppm}$ to $\mathrm{NaCl}$ or $\mathrm{CaCl}_{2}$ reduced mycelial growth to 16 and $23 \%$, respectively. The mechanisms by which sodium salts effect mycelia growth are not known. Regragui and Lahlou [30] showed that the stimulator effect of salinity was observed on the mycelial growth, conidia production, and conidia germination of the tested stain of $V$. dahliae, respectively, in concentrations 170 , 120 , and $256 \mathrm{mM}$ of $\mathrm{NaCl}$. Oppositely, Pelizza et al. [31] showed that the presence of $\mathrm{NaCl}$ in the medium culture reduces the growth of an isolate of Leptolegnia chapmanii. However, Reid et al. [32] reported that sodium chloride was more effective than other chloride salts (calcium chloride, ammonium chloride, and manganese chloride) in controlling Fusarium crown and root rot caused by $F$. oxysporum f. sp. asparagi and F. proliferatum. van Bruggen and Semenov [33] reported that on a long-term basis there is a decrease in the genetic diversity of fungi as a result of stress. On the other hand Zahran [34] mentioned that the hydric stress has to deal with the increase in osmotic pressure and may therefore change their physiology [35] and morphology in response to this [34]. Two strategies used by microorganisms to adapt to osmotic stress were described by Killham [35], both of which result in an accumulation of solutes in the cell to counteract the increase in osmotic pressure. One is the selective exclusion of the solute incorporated (e.g., $\mathrm{Na}^{+}, \mathrm{Cl}^{-}$), thus accumulating the ions necessary for metabolism (e.g., $\mathrm{NH}_{4}^{+}$).

The results of the present study demonstrate that calcium salts also have been shown to reduce mycelial growth in vitro; the percentage of reduction varied between 15 and $34 \%$ as compared to the control. Several studies have reported that calcium applications can suppress diseases caused by several pathogens $[23,27,28,36]$. Our result further supports the results of Maouni et al. [37], who found that calcium chloride significantly reduced pear fruit decay caused by A. alternata and Penicillium expansum when used at 4 and $6 \%$. Tian et al. [38] recorded that calcium chloride at $2 \%$ inhibited the growth and spore germination of $R$. stolonifer, although $\mathrm{CaCl}_{2}$ was tolerated by Alternaria alternata and $P$. expansum in vitro. It was reported that $1,000 \mathrm{mg}$ of calcium (calcium chloride) enhanced the growth of Botryosphaeria dothidea [39]. Calcium salts also have been shown to reduce mycelial growth in vitro and reduce incidence and severity of infection of peach fruits and shoots by Monilinia fructicola and Leucostoma persoonii, respectively [23, 40]. Kaile et al. [24] reported that mycelia cultured with 100 to $200 \mathrm{mM} \mathrm{Ca}^{2+}$ exhibited a lower viability compared with mycelia grown with $10 \mathrm{mM}$ Ca for some isolates of Botrytis spp. While little information is available on the role of $\mathrm{Ca}^{2+}$ in fungi, results of experiments with yeasts have shown that mutants that have defective intracellular $\mathrm{Ca}^{2+}$ transport systems or defective vacuolar $\mathrm{H}^{+}$-ATPase that produces the proton motive force 
necessary for the activity of the vacuolar $\mathrm{Ca}^{2+} / \mathrm{H}^{+}$exchanger [41] could not grow in high $\mathrm{Ca}^{2+}$ concentrations [42-45]. Maintenance of low basal concentrations of free cytosolic $\mathrm{Ca}^{2+}$, in the submicromolar range, is essential for normal cell functions $[46,47]$.

In the case of the evaluation the effect of $\mathrm{NaCl}$ and $\mathrm{CaCl}_{2}$ on the spore production by the fungus, all isolates of $B$. cinerea are able to sporulate in salinity tested, but to varying degrees. The largest sporulation was observed for different concentrations between 50 and $300 \mathrm{ppm}$. The incorporation of $300 \mathrm{ppm}$ salt stimulated the sporulation. In fact, sporangium formation of Phytophthora parasitica in vitro appeared to be stimulated by salinity, as the numbers of sporangia were generally higher (120\% to $225 \%)$ in the salt-amended treatments than the distilled water controls [30]. With regard to conidiogenesis, sodium chloride was significantly higher than those at the other calcium chloride concentrations. Reference [25] showed that stimulation of sporulation under the effect of salinity is due to a specific effect of ions. According to this author, $\mathrm{Na}^{+}$and $\mathrm{Cl}^{-}$stimulate the production of sporangia of $P$. citrophthora and $P$. parasitica while the osmotic effect inhibits biological activity. In Verticillium, increased sporulation under the effect of the salt appears to be not only solely due to the effect of $\mathrm{Na}^{+}$and $\mathrm{Cl}^{-}$ions, but also due to the osmotic effect. However calcium salts did not reduce spore production of $B$. cinerea spores in this study. Similarly, a minimum concentration of calcium is necessary for the production of zoosporangia or zoospore release by Phytophthora spp. [48-50].

In view of these findings, it was reported that, at low concentration $(50 \mathrm{ppm})$, the germination capacity for most isolates increased compared with the control in both types of salt. Beyond this concentration, the effect of $\mathrm{CaCl}_{2}$ resulted in a linear reduction in \% of germination. Similarly, a low reduction of conidial germination was observed for two salt types at the maximum concentration used. Reference [42] showed that increasing the concentration of calcium chloride (25-175 mM) causes a decrease in germination and germ tube growth in vitro of $B$. cinerea and Penicillium expansum, respectively, causing the gray and blue mold in apples stored. Incubating $B$. cinerea spores in increasing concentrations of $\mathrm{CaCl}_{2}\left(4-26 \mathrm{~g} \mathrm{~L}^{-1}\right)$ resulted in decreased spore germination and germ tube growth [51]. Calcium was effective in inhibiting spore germination of $C$. gloeosporioides [23], Rhizopus stolonifer [37], and Alternaria alternata and Penicillium expansum [52]. Physiologically, the maintenance of low basal concentrations of internal $\mathrm{Ca}^{2+}$ is essential for normal cell functions of organisms, and the inability to regulate $\mathrm{Ca}^{2+}$ may affect the organisms' normal growth [53].

Calcium ions may reduce the incidence of fungal infection by directly inhibiting fungal growth and by inhibiting cell wall degrading enzymes produced by the pathogens $[45,54$, 55].

The effects of calcium in reducing spore germination were probably due to toxicity, with high concentrations likely affecting the osmotic balance in fungal cells [56].

\section{Conflict of Interests}

The authors declare that they have no conflict of interests regarding the publication of this paper.

\section{Acknowledgments}

The authors thank M. Benzohra. I. E, Gesmi. A, and Ouabel. $\mathrm{H}$ for their help and Berrahal. $\mathrm{N}$ for their excellent technical assistance.

\section{References}

[1] T. M. O'Neill, D. Shtienberg, and Y. Elad, "Effect of some host and microclimate factors on infection of tomato stems by Botrytis cinerea," Plant Disease, vol. 81, no. 1, pp. 36-40, 1997.

[2] D. Shtienberg, Y. Elad, A. Niv, Y. Nitzani, and B. Kirshner, "Significance of leaf infection by Botrytis cinerea in stem rotting of tomatoes grown in non-heated greenhouses," European Journal of Plant Pathology, vol. 104, no. 8, pp. 753-763, 1998.

[3] S. Kalogiannis, S. E. Tjamos, A. Stergiou, P. P. Antoniou, B. N. Ziogas, and E. C. Tjamos, "Selection and evaluation of phyllosphere yeasts as biocontrol agents against grey mould of tomato," European Journal of Plant Pathology, vol. 116, no. 1, pp. 69-76, 2006.

[4] R. Munns, "Comparative physiology of salt and water stress," Plant, Cell and Environment, vol. 25, no. 2, pp. 239-250, 2002.

[5] S. I. Allakhverdiev, A. Sakamoto, Y. Nishiyama, M. Inaba, and N. Murata, "Ionic and osmotic effects of NaCl-induced inactivation of photosystems I and II in Synechococcus sp.," Plant Physiology, vol. 123, no. 3, pp. 1047-1056, 2000.

[6] H. Koca, M. Bor, F. Özdemir, and I. Türkan, "The effect of salt stress on lipid peroxidation, antioxidative enzymes and proline content of sesame cultivars," Environmental and Experimental Botany, vol. 60, no. 3, pp. 344-351, 2007.

[7] A. Levigneron, F. Lopez, G. Vansuyt, P. Berthomieu, P. Fourcroy, and F. Casse-Delbart, "Les plantes face au stress salin," Cahiers Agricultures, vol. 4, pp. 263-273, 1995.

[8] N. Bouchibi, A. H. C. van Bruggen, and J. D. MacDonald, "Effect of ion concentration and sodium: calcium ratio of a nutrient solution on Phytophthora root rot of tomato and zoospore motility and viability of Phytophthora parasitic," Phytopathology, vol. 80, no. 12, pp. 1323-1329, 1990.

[9] N. S. Blaker and J. D. MacDonald, "The role of salinity in the development of Phytophthora Root Rot of citrus," Phytopathology, vol. 76, no. 10, pp. 970-975, 1986.

[10] J. D. MacDonald, "Effect of salinity stress on the development of Phytophthora root rot of chrysanthemum," Phytopathology, vol. 72, no. 2, pp. 214-219, 1982.

[11] S. Sanogo, "Response of chile pepper to Phytophthora capsici in relation to soil salinity," Plant Disease, vol. 88, no. 2, pp. 205-209, 2004.

[12] T. J. Swiecki and J. D. Macdonald, "Histology of chrysanthemum roots exposed to salinity stress and Phytophthora cryptogea," Canadian Journal of Botany, vol. 66, no. 2, pp. 280-288, 1988.

[13] E. Turco, D. Naldini, and A. Ragazzi, "Disease incidence and vessel anatomy in cotton plants infected with Fusarium oxysporum f. sp. vasinfectum under salinity stress," Zeitschrift für Pflanzenkrankheiten und Pflanzenschutz, vol. 109, no. 1, pp. 15-24, 2002. 
[14] J. P. Jones, J. B. Jones, S. S. Woltz, and J. W. Scott, "Influence of soil $\mathrm{pH}$, nitrogen source, and transplant drenches on development of crown rot of tomato," Proceedings of the Florida State Horticultural Society, vol. 106, pp. 170-172, 1993.

[15] A. Nachmias, Z. Kaufman, L. Livescu, L. Tsror, A. Meiri, and P. D. S. Caligari, "Effects of salinity and its interactions with disease incidence on potatoes grown in hot climates," Phytoparasitica, vol. 21, no. 3, pp. 245-255, 1993.

[16] H. Marschner, Mineral Nutrition of Higher Plants, Academic Press, London, UK, 2nd edition, 1995.

[17] J. B. Hanson, "The function of calcium in plant nutrition," in Advances in Plant Nutrition, P. B. Tinker and A. Läuchli, Eds., pp. 149-208, Praeger, New York, NY, USA, 1984.

[18] D. S. Bush, "Calcium regulation in plant cells and its role in signaling," Annual Review of Plant Physiology and Plant Molecular Biology, vol. 46, pp. 95-122, 1995.

[19] G. R. Chaplin and K. J. Scott, "Association of calcium in chilling injury susceptibility of stored avocados," Hortscience, vol. 15, pp. 514-515, 1980.

[20] W. S. Conway, K. C. Gross, and C. E. Sams, "Relationship of bound calcium and inoculum concentration to the effect of postharvest calcium treatment on decay of apples by Penicillium expansum," Plant Disease, vol. 71, no. 1, pp. 78-80, 1987.

[21] W. S. Conway, K. C. Gross, C. D. Boyer, and C. E. Sams, "Inhibition of Penicillium expansum polygalacturonase activity by increased apple cell wall calcium," Phytopathology, vol. 78, no. 8, pp. 1052-1055, 1988.

[22] R. G. McGuire and A. Kelman, "Calcium in potato tuber cell walls in relation to tissue maceration by Erwinia carotovora pv. atroseptica," Phytopathology, vol. 76, no. 4, pp. 401-406, 1986.

[23] A. R. Biggs, M. M. El-Kholi, S. El-Neshawy, and R. Nickerson, "Effects of calcium salts on growth, polygalacturonase activity, and infection of peach fruit by Monilinia fructicola," Plant Disease, vol. 81, no. 4, pp. 399-403, 1997.

[24] A. Kaile, D. Pitt, and P. J. Kuhn, "Calcium cytotoxicity, protoplast viability and the role of calcium in soft-rot of Brassica napus due to Botrytis cinerea Pers," Physiological and Molecular Plant Pathology, vol. 40, no. 1, pp. 49-62, 1992.

[25] M. Wisniewski, S. Droby, E. Chalutz, and Y. Eilam, "Effects of $\mathrm{Ca}^{2+}$ and $\mathrm{Mg}^{2+}$ on Botrytis cinerea and Penicillium expansumin vitro and on the biocontrol activity of Candida oleophila," Plant Pathology, vol. 44, no. 6, pp. 1016-1024, 1995.

[26] D. F. Bateman and R. D. Lumsden, "Relation of calcium content and nature of the pectic substances in bean hypocotyls of different ages to susceptibility to an isolate of Rhizoctonia solani," Phytopathology, vol. 55, pp. 734-773, 1965.

[27] W. S. Conway, C. E. Sams, R. M. McGuire, and A. Kelman, "Calcium treatment of apples and potatoes to reduce postharvest decay," Plant Disease, vol. 76, no. 4, pp. 329-334, 1992.

[28] H. Volpin and Y. Elad, "Influence of calcium nutrition on susceptibility of rose flowers to Botrytis blight," Phytopathology, vol. 81, no. 11, pp. 1390-1394, 1991.

[29] H. Benyahyia, Effect of Salinity on Root Rot of Citrus Caused by Phyhophthora Parasitica, edited by: D. E. S. Ducan, Cadi Ayyad University, Marrakesh, Morocco, 1998.

[30] A. Regragui and H. Lahlou, "Effect of salinity on in vitro Trichoderma harzianum antagonism against Verticillium dahliae," Pakistan Journal of Biological Sciences, vol. 8, no. 6, pp. 872-876, 2005.

[31] S. A. Pelizza, C. C. L. Lastra, J. J. Becnel, V. Bisaro, and J. J. García, "Effects of temperature, $\mathrm{pH}$ and salinity on the infection of Leptolegnia chapmanii Seymour (Peronosporomycetes) in mosquito larvae," Journal of Invertebrate Pathology, vol. 96, no. 2, pp. 133-137, 2007.

[32] T. C. Reid, M. K. Hausbeck, and K. Kizilkaya, "Effects of sodium chloride on commercial asparagus and of alternative forms of chloride salt on Fusarium crown and root rot," Plant Disease, vol. 85, no. 12, pp. 1271-1275, 2001.

[33] A. H. C. van Bruggen and A. M. Semenov, "In search of biological indicators for soil health and disease suppression," Applied Soil Ecology, vol. 15, no. 1, pp. 13-24, 2000.

[34] H. H. Zahran, "Diversity, adaptation and activity of the bacterial flora in saline environments," Biology and Fertility of Soils, vol. 25, no. 3, pp. 211-223, 1997.

[35] K. Killham, Soil Ecology, vol. 1, Cambridge University Press, Cambridge, UK, 1994.

[36] H. Yamazaki and T. Hoshina, "Calcium nutrition affects resistance of tomato seedlings to bacterial wilt," HortScience, vol. 30, no. 1, pp. 91-93, 1995.

[37] A. Maouni, A. Lamarti, A. Aidoun, M. Khaddor, and A. Badoc, "Effect of benzimidazole fungicides and calcium chloride on Alternaria alternata and Penicillium expansum rot during storage of pears," African Journal of Biotechnology, vol. 6, no. 11, pp. 1289-1292, 2007

[38] S. P. Tian, Q. Fan, Y. Xu, and A. L. Jiang, "Effects of calcium on biocontrol activity of yeast antagonists against the postharvest fungal pathogen Rhizopus stolonifer," Plant Pathology, vol. 51, no. 3, pp. 352-358, 2002.

[39] A. R. Biggs, "Effect of inoculum concentration and calcium salts on infection of apple fruit by Botryosphaeria dothidea," Plant Disease, vol. 88, no. 2, pp. 147-151, 2004.

[40] A. R. Biggs and C. A. Peterson, "Effect of chemical applications to peach bark wounds on accumulation of lignin and suberin and susceptibility to Leucostoma persoonii," Phytopathology, vol. 80, no. 9, pp. 861-865, 1990.

[41] Y. Ohsumi and Y. Anraku, "Calcium transport driven by a proton motive force in vacuolar membrane vesicles of Saccharomyces cerevisiae," Journal of Biological Chemistry, vol. 258, no. 9, pp. 5614-5617, 1983.

[42] K. W. Cunningham and G. R. Fink, "Calcineurin-dependent growth control in Saccharomyces cerevisiae mutants lacking PMC1, a homolog of plasma membrane Ca2+ ATPases," The Journal of Cell Biology, vol. 124, no. 3, pp. 351-363, 1994.

[43] F. Foury, "The 31-kDa polypeptide is an essential subunit of the vacuolar ATPase in Saccharomyces cerevisiae," The Journal of Biological Chemistry, vol. 265, no. 30, pp. 18554-18560, 1990.

[44] D. Halachmi and Y. Eilam, "Cytosolic and vacuolar $\mathrm{Ca}_{2}^{+}$ concentrations in yeast cells measured with the $\mathrm{Ca} 2^{+}$-sensitive fluorescence dye indo-1," FEBS Letters, vol. 256, no. 1-2, pp. 5561, 1989.

[45] Y. Ohya, Y. Ohsumi, and Y. Anraku, "Isolation and characterization of $\mathrm{Ca}^{2+}$-sensitive mutants of Saccharomyces cerevisiae," Journal of General Microbiology, vol. 132, no. 4, pp. 979-988, 1986.

[46] E. Carafoli, "Intracellular calcium homeostasis," Annual Review of Biochemistry, vol. 56, pp. 395-433, 1987.

[47] H. Rasmussen and J. E. Rasmussen, "Calcium as intracellular messenger: from simplicity to complexity," Current Topics in Cellular Regulation, vol. 31, pp. 1-109, 1990.

[48] D. M. Halsall and R. I. Forrester, "Effects of certain cations on the formation and infectivity of Phytophthora zoospores. 1. Effects of calcium, magnesium, potassium, and iron ions," 
Canadian Journal of Microbiology, vol. 23, no. 8, pp. 994-1001, 1977.

[49] N. Sato, "Effect of some inorganic salts and hydrogen ion concentration on indirect germination of the sporangia of Phytophthora infestans," Annals of the Phytopathological Society of Japan, vol. 60, no. 4, pp. 441-447, 1994.

[50] S. L. Von Broembsen and J. W. Deacon, "Calcium interference with zoospore biology and infectivity of Phytophthora parasitica in nutrient irrigation solutions," Phytopathology, vol. 87, no. 5, pp. 522-528, 1997.

[51] C. O. Chardonnet, C. E. Sams, and W. S. Conway, "Calcium effect on the mycelial cell walls of Botrytis cinerea," Phytochemistry, vol. 52, no. 6, pp. 967-973, 1999.

[52] A. R. Biggs, "Effects of calcium salts on apple bitter rot caused by two Colletotrichum spp," Plant Disease, vol. 83, no. 11, pp. 10011005, 1999.

[53] A. R. Biggs, M. Ingle, and W. D. Solihati, "Control of Alternaria infection of fruit of apple cultivar nittany with calcium chloride and fungicides," Plant Disease, vol. 77, no. 10, pp. 976-980, 1993.

[54] W. S. Conway and C. E. Sams, "Possible mechanisms by which post-harvest calcium treatment reduces decay in apples," Phytopathology, vol. 74, no. 2, pp. 208-210, 1984.

[55] S. Droby, M. E. Wisniewski, L. Cohen et al., "Influence of CaCl2 on Penicillium digitatum, grapefruit peel tissue, and biocontrol activity of Pichia guilliermondii," Phytopathology, vol. 87, no. 3, pp. 310-315, 1997.

[56] G. Arras, P. Sanna, V. Astone, and S. Arru, "Effect of calcium chloride on the inhibitory activity of Rhodotorula glutinis against Penicilium italicum on orange fruits," Italus Hortus, vol. 5, pp. 67-70, 1998. 

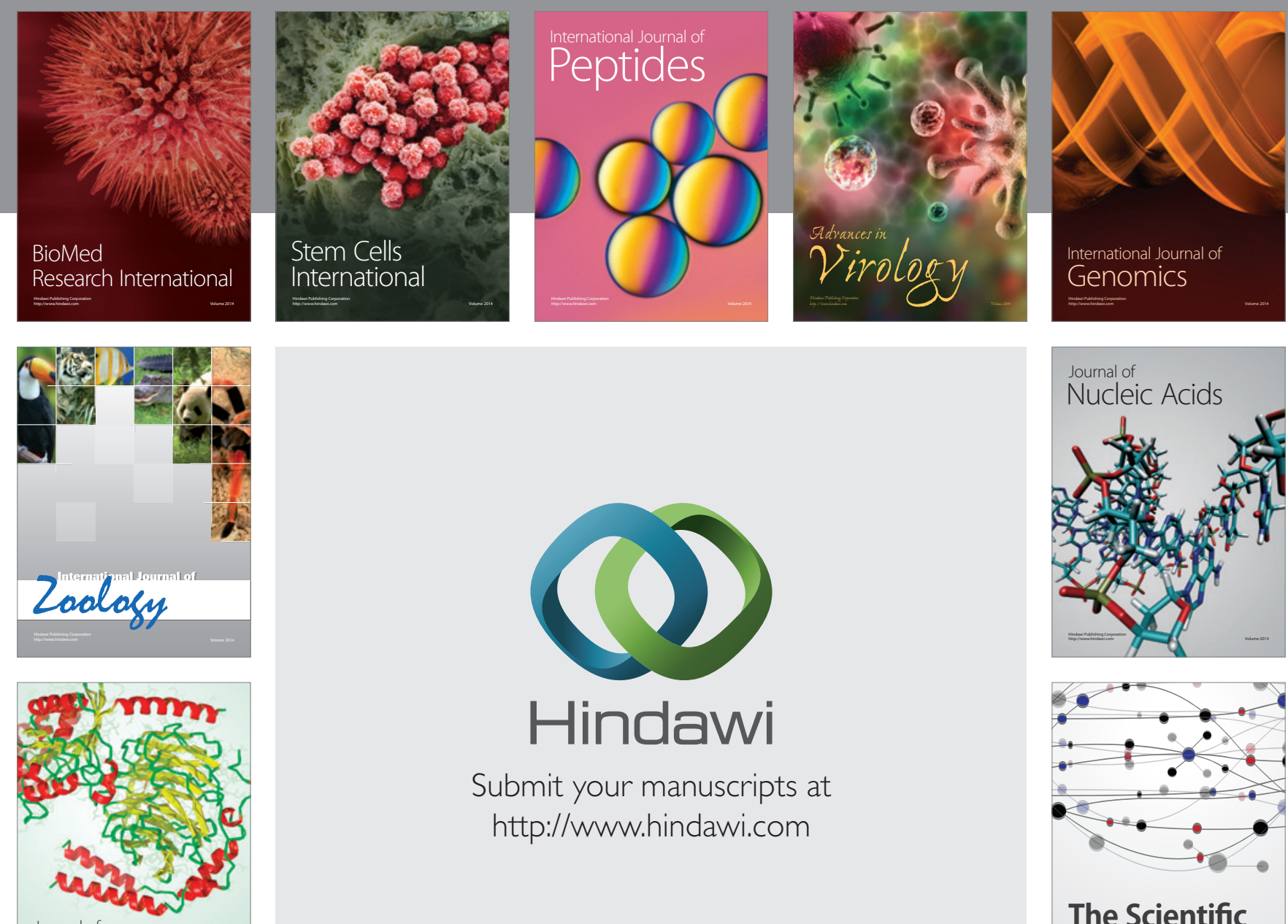

Submit your manuscripts at

http://www.hindawi.com

Journal of
Signal Transduction
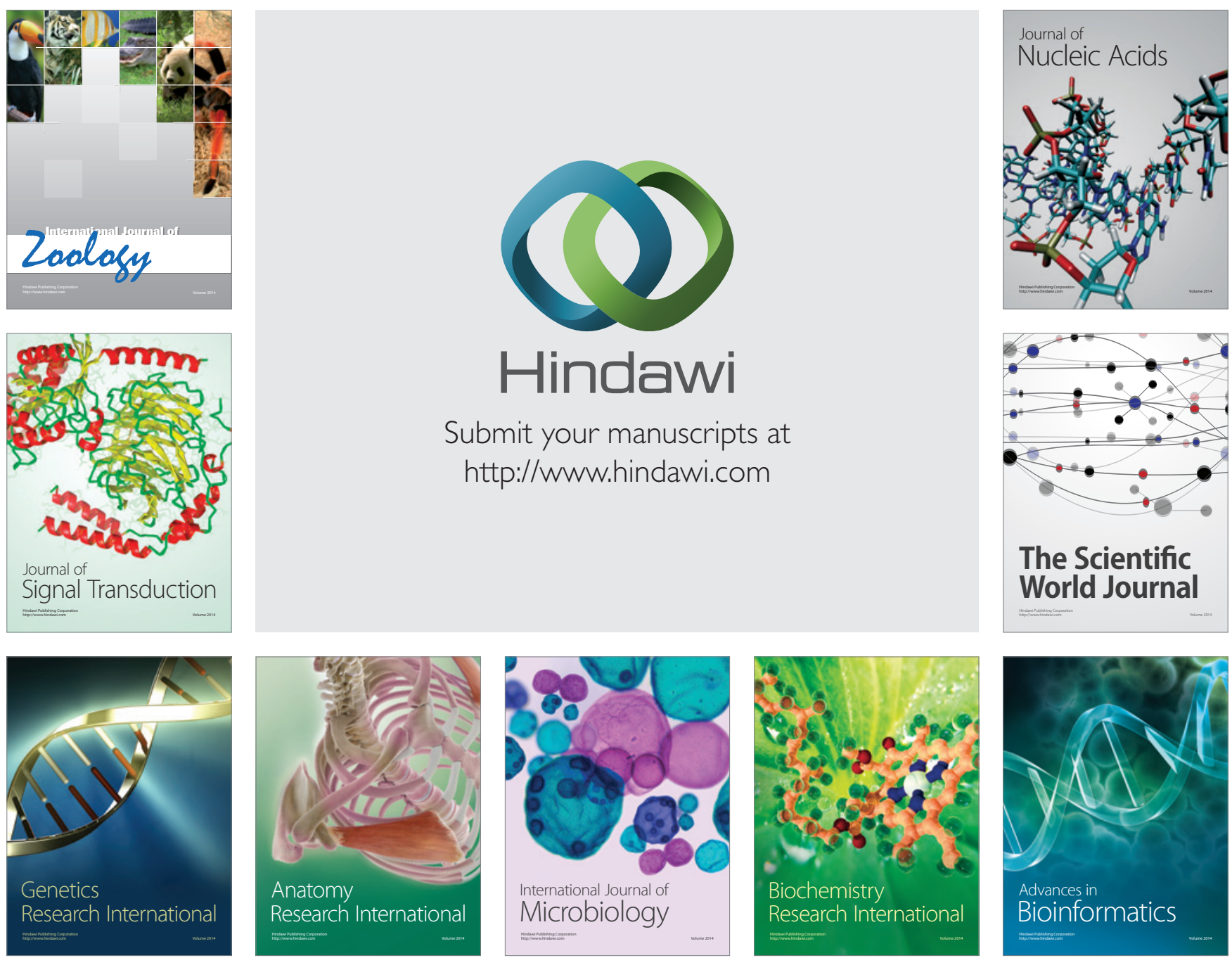

The Scientific World Journal
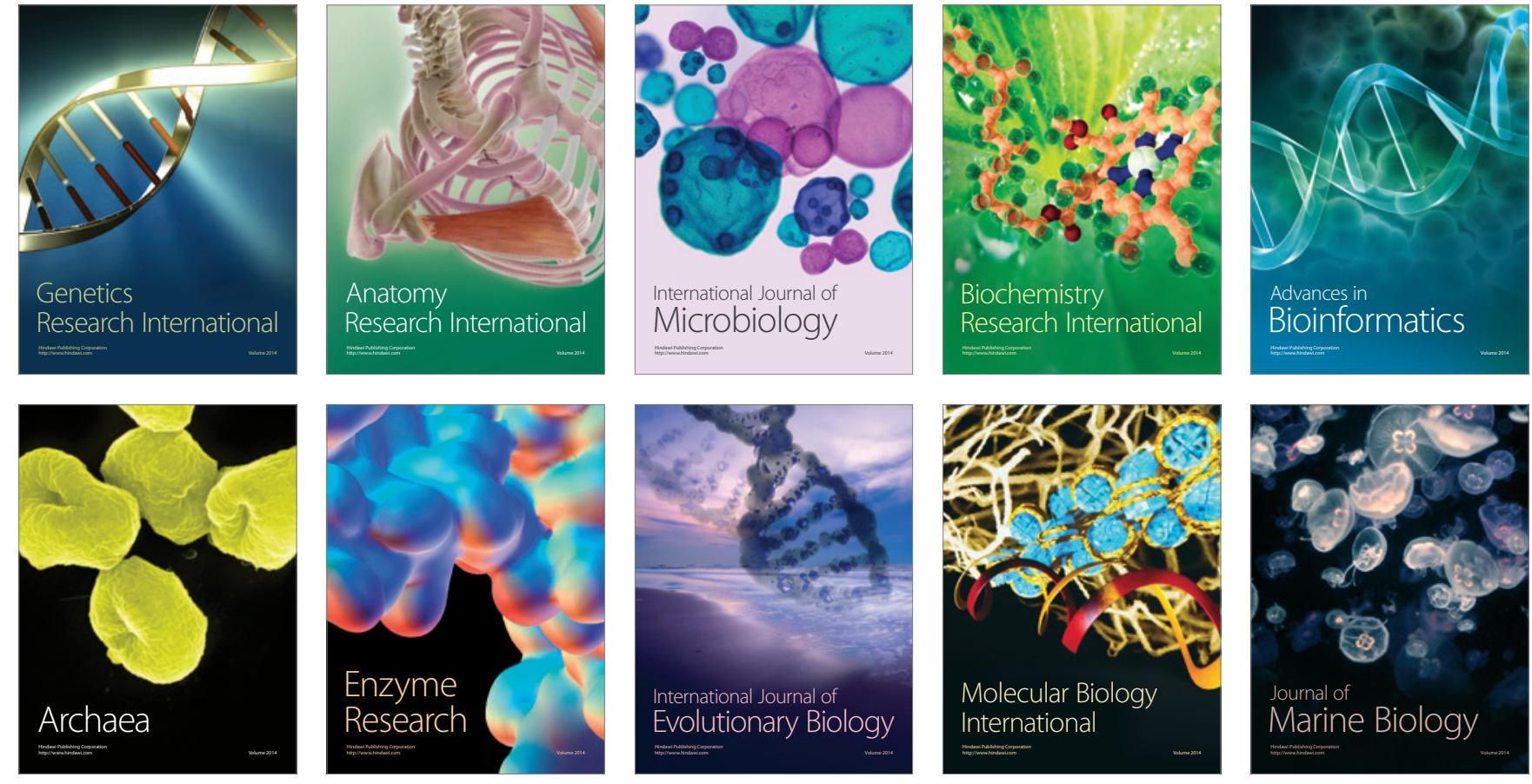